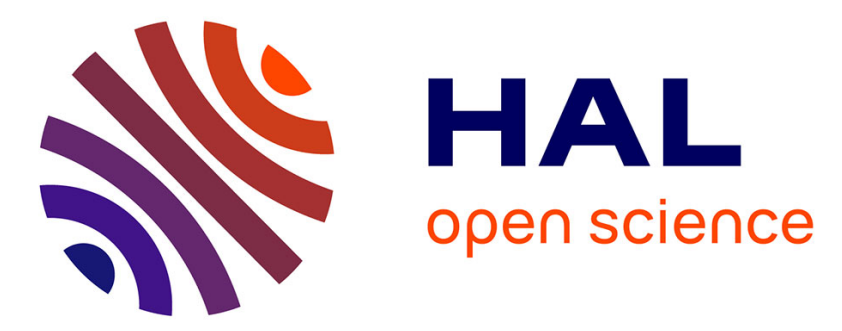

\title{
Information Systems Education for Development: A Typology of ICT4D Pedagogies
}

\author{
Gwamaka Mwalemba
}

\section{To cite this version:}

Gwamaka Mwalemba. Information Systems Education for Development: A Typology of ICT4D Pedagogies. 15th International Conference on Social Implications of Computers in Developing Countries (ICT4D), May 2019, Dar es Salaam, Tanzania. pp.337-348, 10.1007/978-3-030-19115-3_28 . hal02281297

\section{HAL Id: hal-02281297 \\ https://hal.inria.fr/hal-02281297}

Submitted on 9 Sep 2019

HAL is a multi-disciplinary open access archive for the deposit and dissemination of scientific research documents, whether they are published or not. The documents may come from teaching and research institutions in France or abroad, or from public or private research centers.
L'archive ouverte pluridisciplinaire HAL, est destinée au dépôt et à la diffusion de documents scientifiques de niveau recherche, publiés ou non, émanant des établissements d'enseignement et de recherche français ou étrangers, des laboratoires publics ou privés. 


\title{
Information Systems Education for Development: A Typology of ICT4D Pedagogies
}

\author{
Gwamaka Mwalemba \\ University of Cape Town, Cape Town, South Africa \\ gt.mwalemba@uct.ac.za
}

\begin{abstract}
This paper is an attempt to position Information Systems (IS) education within the Information and Communications Technologies for Development (ICT4D) research and practice discourse. The motivation for the study comes from an understanding that, while the research on ICT4D theories and practice has grown in popularity, there has been very little effort directed towards establishing the link between university education and ICT4D practices. IS education literature is still preoccupied with discussions on curriculum and pedagogies focused on equipping students with instrumental knowledge grounded on the 'catching up' and 'conformist' IS practices. As a result learners,especially at the undergraduate level, are left with little to no exposure to the IS discourses of reformists and transformists that have been identified as critical to the success of ICT4D. By drawing parallels to other patterns in ICT4D research and practice, this study hopes to shed light on a gap in IS education that, if not addressed, will continue to be a major obstacle to ICT4D initiatives in developing countries.
\end{abstract}

Keywords: IS Education, Curriculum, Pedagogy, ICT4D

\section{Introduction}

In the past two decades, the role of Information Systems (IS) as a discipline has been discussed, as has, to some extent, the role of Information and Communication Technologies (ICTs) in general. These discussions have evolved beyond any pre-occupation with attaining a competitive advantage through improving productivity and efficiency within organizations [1]. One of the new discourses is that concerned with how Information Systems are implicated in the process of national (as well as regional) development, specifically in the context of developing countries. In this stream, many studies on IS and its implication to various socio-economic and political discourses such as public health, access to education, access to information, promotion of human rights, as well as democracy and freedom, just to name a few [2,3,4].

While the focus on the social implications of IS has however, generated many useful theoretical as well as practical insights, some areas of research have been largely ignored. One such area is the role of education, especially undergraduate education, in engaging challenges that are repeatedly being raised by ICT4D [5]. This is particularly alarming, considering what is already known of the impact of education in facilitating and sustaining systemic changes within societies [6]. 
This paper represents efforts to position IS education within the ICT4D discourse. It does so by first unpacking the link between development and ICTs. It then uses the work of Avgerou [7] and Roberts [8] to lay a foundation on a typology of ICT4D practices in developing countries. This typology is then juxtaposed with the work of education scholars in order to draw parallels and subsequently establish if there are any useful insights. The intended contribution of this research work is to challenge and subsequently improve - or at least diversify - the existing assumptions, beliefs and challenges embedded within IS education, specifically in contexts where the colonial structures still perpetuate and manifest themselves in the interaction of society and ICTs as well as in the relationship between developing and developed countries.

\section{Development in the ICT4D Discourse}

The term 'development as used in ICT4D discourse is largely associated with Sen's conceptualization of development as the ability to freely choose and pursuit the kind of life one values [9]. In ICT4D, development is often associated with efforts to help individuals, especially those in underdeveloped countries, not only gain access to basic human needs but also freely pursue opportunities that they value. However, despite wider acceptance of Sen's conceptualization of development, a careful analysis of ICT4D scholarly work still points to great interest and emphasis on technology (technology determinism) presenting it either as a silver bullet to solving developmental challenges or as development in itself $[10,11]$.

There have, over the years, been increasing calls for more theorization of the 'development' aspect of ICT4D [10,12,13,14,15]. This is partly because of the growing internationalization and multidisciplinary involvement in ICT4D efforts. It is now increasingly common to have academics and researchers from different fields, policymakers, and practitioners all attempting to collaborate in the ICT4D space. There is also the mix of grassroots-level or locally born initiatives and those which are set up and driven by funds from large donors and international agencies. All these stakeholders have different interpretations of development and ways of achieving it, often shaped by their historicity, composition, interests, values and a multitude of other agendas.

\section{The Role of Technology in Development}

Since some background to the concept of development and the efforts to achieve such development has been provided, it is now possible to unpack the role of technology, specifically from the perspective of developing countries. In order to do this, various assumptions, values, and interests that shape the role of IS will also be examined, as will subsequently its practices and research into it.

One of the typical issues highlighted by studies on IS practices in developing countries involves investigating the implication of introducing to a developing country technologies or practices, typically those that originate from western countries, such as ERP systems, project management, and business process management,. The ratio- 
nale is that developing countries can take advantage of these technologies or practices to 'catch up' by imitating or replicating their success [16]. In some cases, these studies will acknowledge the contextual challenges and will make recommendations which involve modifying aspects of the practices or technical functionalities as a means to address the contextual differences. Heeks refers to such innovation that emerges outside the context of developing countries as 'pro-poor' innovation and highlights their susceptibility to 'design versus reality gap' [17]. This phenomenon has also been observed in the context of technology adoption in small, medium and micro-scale enterprises in South Africa and Tanzania [18]. In their analysis of what they referred to as 'thin 'and 'thick' forms of technology integration, they warned of the potential to marginalize the local industries which were supposed to benefit from such technology adoption [18]. For the sake of this study, this first role will be referred to as a transfer and diffusion perspective in line with Avgerou's classification [7].

The second classification on how technology is conceptualized in relation to development is that which strongly believes that technology can only make a meaningful impact in developing countries if it's deeply integrated with the needs and practices emerging from the local context. Avgerou refers to this approach as 'socially embedded' [7]. Here, the emphasis is on solving problems as defined by local actors through following a socially and locally construed IS-innovation process, taking into consideration the values, priorities, and meanings emerging from the context. The many challenges that have emerged from the transfer and diffusion approach have convinced local and international policymakers as well as various development agencies to question this approach. However, some researcher are skeptical of this approach especially with regard to the type of local actors involved in these initiatives and the reasons for their participation [17].

Both the transfer and diffusion as well as the socially embedded approaches often take for granted the relationship between technology and development [12]. This has the risk of falling into the trap of seeing the use of technology as the development of itself and ignore not only the potential implication of such usage but also the issue of whom the real beneficiary is [10]. There are many cases where technology has been introduced as a way of providing local communities with access to information but ended up converting community members into perpetual consumers of western products and cultures [18]. From an organisational perspective, there are numerous cases when the introduction of technology has resulted not only to efficiency but also to a dependency on technology, practices, and expertise that are only from overseas, resulting in a significant outflow of cash and other economic benefits from the developing country [16].

The last approach, referred to as 'transformative', is critical of the relationship between technology and development. It questions the many assumptions behind the development in question as well as how technology is implicated [7]. The transformative approach is also critical of the kind of social, economic and political changes that are facilitated through technology. It is concerned with the resultant power imbalances as well as the wellbeing of the vulnerable and marginalized. For the perspective of transformation, the role of IS is to enhance individuals' agency, especially those 
subjected to marginalisation and oppression, to challenge the status quo and achieve the kind of development they value [13]. The transformative approach posits that the involvement of local actors does not always guarantee an outcome that contributes to the wellbeing of the local community. There are many examples when local actors used technology to promote local practices, norms and values that violate the rights, dignity and wellbeing of other people [13,17]. Sen even warns about the possibility of 'adaptive preferences', a condition where people in desperate conditions normalize their suffering, deprivation, oppression or any other challenge, typically as a psychological defensive mechanism to mitigate their pain [19].

Avgerou's classification of IS innovation in developing countries is aligned with at least two other similar analyses, one focusing on IS research and other on ICT4D practices [7]. The first one is an analysis of assumptions about social reality within the three dominant IS research streams namely positivist, interpretive, and critical research $[20,21]$. While their analysis is more detailed, only the part relevant to the comparison with the three categories of IS innovation proposed in [7] will be focused on. According to their analysis, positivist research is seen to be most concerned with measurement and the accurate representation of objective reality on IS practices in organizations. This focus on measurement is grounded on the overall objective to measure, manage and replicate the impact of IS practices in an organization - or any other given context for that matter. This approach seems to form the foundation of what Avgerou has described as the transfer and diffusion approach [7].

The second category is that of interpretive research. Interpretive IS research conceptualizes IS as social systems intentionally enacted and embedded in the way people accomplish their tasks [20]. Interpretive research in IS practices is, therefore, grounded on an understanding that the design, usage, and benefits of IS are based on the experiences of local actors in a particular cultural and social context. This category is aligned with Avgerou's socially embedded approach [7].

The third and last category is that of critical IS research [21]. This perspective sees IS interventions in organization as not only been shaped by social and cultural factors but as a process with historicity that has great implications for social structures and power relations. This approach is concerned with exploring deeper structures and in revealing hidden forces that are often ideologically inscribed and are a subject of a long and continuously evolving history [20]. Perhaps one of the most distinguishing features of the third category is its emphasis on IS research that takes an explicit stance on its values and that is grounded on confronting and transforming asymmetric power relations in society [21]. With transformation as one of its core principles, this third category can be seen to be closely aligned with the transformative category in the Avgerou classification [7].

The final analysis focuses on ICT4D practices and is closely aligned with Avgerous's categorization of IS innovation. This ICT4D typology builds on the work of Ineke Buskens, and divides the 'intent' of ICT4D initiatives into three categories, namely, conformist, reformist, and transformist [8]. Conformist ICT4D, as the name suggests, has no intention of disrupting the status quo but rather aims to improve efficiency within the existing hegemonic development paradigm. As a result, conformist ICT4Ds are prone to making use of IS or ICTs to further the already existing 
marginalization and exploitation that is embedded in some development initiatives. On the contrary, reformists ICT4D initiatives are intended to address issues related to inequality or marginalisation. However, this is usually done without challenging the underlying structural causes of such inequality and marginalization. Most ICT4D initiatives fall under this category [8]. Lastly, transformist ICT4D initiatives, as the name suggests, are aimed specifically at transforming the underlying structural and historical causes of any form of marginalization or asymmetric power relations in developing countries. They pay special attention to issues of gender, race and class relations, as well as any colonialist or imperialist agendas within the development discourse. The conformist, reformist and transformist approaches to ICT4D are largely aligned to to Avgerous's transfer and diffusion, socially embedded, as well as the transformative categories.

It is important to highlight that the categories or perspectives discussed represent more of a continuum than an exclusive relationship. Furthermore, all three analyses have carefully avoided to paint a view that one category is somehow superior to another. However, all three analyses indicate that IS and ICT4D research and practices predominantly embrace positivist and instrumentalist worldviews with a preference for initiatives that place emphasis improving efficiency and controls. There are very limited IS initiatives that are fully grounded on critical perspectives and aimed at challenging asymmetric power relations in organizations as well as in society.

\section{The role of Education in Development}

The role of education in developing countries, like that of technology, is a complex phenomenon. For most developing countries, the pre-colonial education system was aimed at passing on contextually grounded knowledge from one generation to another. Education played many roles, it was essential for exposing the younger generation to skills necessary for their day-to-day survival in a given context. It was also a source of exploration and innovation through mixing the as lived experiences of the older generation and the energy and curiosity of the younger generation, and was a way of socializing younger generations to the norms and customs of their community [22].

With colonialism came formalised forms of education. As history would put it, education was one of the means used by colonialists to evangelise and indoctrinate the colonised with their imperialistic and capitalistic interests and values including, among other things, the technology-deterministic, market-driven economic theories and the superiority of western epistemologies [23, 24].

Most of the well-established postcolonial universities are, in fact, products of the colonial project. Their conceptualisation was based on the imaginations and needs of the imperial and colonial project which was primarily concerned with the interest of the western industrialized nations, the colonizers. This meant that after the end of colonialism it was imperative for universities to undergo serious transformation to free themselves from their colonial legacy and embrace a new, locally emergent, agenda for the benefits of previously colonized. However, decades after political inde- 
pendence very little progress has been made in terms of transforming and decolonizing universities in many developing countries, including in sub-Saharan Africa. One can even argue that, in some cases, universities have even taken a step backward by abandoning the scholarly activism that was on the forefront of the fight against imperialism and colonialism and that had gained significant momentum in the 1960s especially in universities such as the Makerere University in Uganda and Tanzania's University of Dar-es-Salaam. It would seem, nowadays, that universities are increasingly competing for recognition and assimilation into western academic standards and as well are embracing asymmetric relationships with capitalistic multinational corporations in the search for funding and opportunities for students' employment [22,25].

\section{Curriculum and Pedagogy in Postcolonial Education}

Pedagogy of the Oppressed by Paulo Freire is arguably the most influential scholarly work to date on the critical analysis of colonial and postcolonial education in the context of developing countries [6]. It focuses specifically on the relationship between students, teachers and their society. Through his experience of working with poor and marginalized Brazilian adults as they learn to read and write, Freire's work presents a detailed analysis of the relationship between the oppressed and the oppressor as well as the colonizer and the colonized within the educational context. Freire's analysis categorizes two modes of education, one that is based on hegemonic colonial epistemology and ontology and another which he proposes as an alternative. The two modes are the 'banking model' (or concept) of education as well as the 'problem-posing' model of education. Freire describes the banking model as one directional relationship where the student is a perpetual receiver of often decontextualised knowledge and the teacher is a narrator [6]. It is oppressive and meant to create students who are incapable of critical thinking and unable to come up with inventions or transformation that can meaningfully advance their well-being. The banking education model was conceptualized by - and is linked to - the interests of colonisers who were only educating the colonised for the purpose of using them to advance their colonial and imperialistic interests [6]. By continuously participating in the banking education model, educators, knowingly or unknowingly, are socializing with an education system designed to oppress learners instead of empowering them.

The ontological and epistemological assumptions embedded in the banking education share similarities with the positivist and transfer and diffusion approaches $[7,21,26$,$] . There is an assumption of objective decontextualised reality, which can be$ discovered and passed on objectively as knowledge [6].

As an alternative to banking education, Freire proposed another form of bi-directional, critical and, hence, transformational education and name it as 'problem-posing' education [6]. Problem-posing education sees both educators and students as cognitive actors engaging in a process of mutual learning through dialogue. Students assume the role of critical co-investigators and are expected to know, engage and recreate knowledge instead of just memorising. The objective is to develop a reflective and critical consciousness and subsequently critical agency which is instrumental for in- 
novation and transformation of the social world. These objectives bear similarities with those critical of IS research and transformative IS innovation [7,21].

Another useful analysis of education comes from Miller \& Seller, whose work on the role of education focuses on the curriculum and its ontological and epistemological implications [27]. They define curriculum as a set of interactions carefully designed to facilitate learning, development and interpretation of experience [27]. This includes the explicitly documented curricula as well as the implicit norms and rules or expectations commonly referred to as 'hidden curriculum'. Echoing Freires work, categorizations of education in Miller and Seller highlight two extreme curriculum perspectives: one extreme which involves students merely absorbing or memorizing information and another that involves a deeper and mutual interaction between student and educator as they cooperatively solve problems [6,27]. However, Miller and Seller take their analysis a step further by presenting three curriculum positions that are shaped by assumptions on the role of education. The three positions are transmission, transaction, and transformation [27]. These positions are informed by assumptions or beliefs on issues such as the overall aim of education, the conception of the learner, the learning process and the learning environment, conceptions on the role of the educator as well as how learning should be evaluated. Furthermore, the transmission position sees the role of education as the transmission of knowledge in the form of facts, skills and values to students. Knowledge is seen as objective, essential for prediction and control, and its transmission is one directional. The transmission position can be traced back to colonial times and is grounded on the philosophy of logical positivism and is closely linked to capitalism and conservative economic theories. The transaction position is based on assumptions that students are rational beings with agency. Education involves dialogue between students and the curriculum and is aimed at problem-solving in a given context guided by a democratic processes. Lastly, the transformation position sees education as a vehicle for driving personal and social changes. It assumes a more critical view of the role of education in a society which involves political and social activism that challenges the dominant economic interests [27].

This analysis of perspectives of education, summarized in Table1, sets the scene for the analysis that links IS education to the assumptions and perspectives on the role of IS, IS research and ICT4D practices.

Table 1. A typology of IS/ICT4D research, practice \& education

\begin{tabular}{|l|l|l|l|l|}
\hline & \multicolumn{2}{|l|}{ Perspectives } & Source \\
\hline IS Research & Positivist & Interpretive & Critical & {$[21]$} \\
\hline IS Innovation & $\begin{array}{l}\text { Transfer \& dif- } \\
\text { fusion }\end{array}$ & Socially embedded & Transformative & {$[7]$} \\
\hline ICT4D practices & Conformist & Reformist & Transformist & {$[8]$} \\
\hline Curriculum & Transmission & Transaction & Transformative & {$[27]$} \\
\hline Pedagogy & Banking & {$[6]$} \\
\hline
\end{tabular}




\section{Information Systems Curriculum}

Information Systems is a young discipline as far as higher education is concerned. Its formal recognition as a discipline or field of study dates back to the late 1960s and early 1970s, when for the first time billions of US dollars were being invested in equipment and people involved with computers and data communication in the United States alone [28]. Then referred to as Management Information System (MIS), it combined concepts from numerous other existing disciplines such as Computer Science, Management and Organisation Theory, Operations Research, and Accounting [1].

There are reports that point to universities offering IS/MIS undergraduate programs as far back as 1966 [1]. However, the first formal IS curriculum for higher education studies can only be traced back to 1972 ,when the Association of Computing Machinery (ACM) published a report with a set of guidelines for new and existing graduate level IS programs. The report, which consisted of course outlines and recommendations for new specialisations, was an outcome of a work done by a ten-member, US-based, committee in consultation with industry and academia [29]. The committee then went on to create another set of guidelines targeting undergraduate IS degree program. The undergraduate curriculum was released by ACM in 1973 with the intention of providing guidance for the design of an IS program, with the expectation that IS departments in universities would modify and adapt it to fit their own context [30].

While ACM was driving IS curriculum discussion in the United States, another organisation known as the International Federation of Information Processing (IFIP) was doing similar work in Europe. In 1974, IFIP's Technical Committee for Education (TC3) and the Administrative Data Processing Group (IAG) proposed an IS curriculum specifically focusing on system designers. Several well-established institutions such as the London School of Economics and the Royal Military College of Science adopted the curriculum [1]. Other curriculum initiatives in the 1980s and 1990s include a curriculum called the Data Processing Management Association (DPMA), published in 1981, and the IEEE software engineering curriculum which was published in 1999.

In 1994, the Association for Information Systems (AIS), an international association for IS academics, was formed [1]. Three years later, the IS curriculum was revised by representatives from AIS, ACM, and Association of Information Technology (AITP, formerly DPMA). This led to the release of what was then considered as the first international IS curriculum known as the IS 1997 Model Curriculum [31]. The IS 1997 Model Curriculum was later reviewed and updated to create the IS 2002 curriculum and also the most recent version, IS 2010 Curriculum [32].

This history of the development of the IS curriculum is important as it puts the discipline into context and reveals several issues that are of interest. For instance, what is now considered as the international IS curriculum is predominantly a product of two regional IS bodies, Europe and North America, with each region bringing to the table its unique institutional characteristic. The review body for the initial IS 97 model as well as the IS 2010 curriculum were exclusively constituted by academics and specialists from European and American institutions. This is important because while the 
review process, especially for the IS2010 curriculum, has made efforts to be as consultative as possible, the process is still subjective and the final decision on what should be included or excluded lies with the review team. This is supported by observations from other researchers who have pointed out the fact that the curriculum, to a great extent, aligns IS with business faculties which is typical in North American institutions where most of the review body members are based [33,34].

Furthermore, while the IS discipline is young, it is also in many ways implicated in the issues of unequal power relations between the dominant western and often capitalistic discourse and the 'Other'. This dichotomy becomes even more prevalent when one observes the research and teaching of IS in developing countries. There the discipline is still dominated by positivism and grounded in western ways of being and knowing $[35,36]$. This can be partially attributed to the infancy of the IS discipline which has resulted to a scenario whereby most senior IS academics, especially those in developing countries, have a background in mathematics, statistics or computer science. Furthermore, In many cases, the ICT departments/faculties/schools in developing countries were established in partnership with 'parent' universities from the West and accompanied with a flow of Western academics to Africa to help 'set-up' and develop local capacity to run the computing units. Overtime IS (or Informatics) departments started to emerge, often as sub-units in accounting, management and, in some cases, computer science (or ICT). The newly established IS departments would then be run by academics with MIS qualification from overseas. These departments emulated the courses and research focus of their Western counterparts (or 'parents'). This was accompanied by efforts to implement an 'international' curriculum as a way to gain legitimacy [5,37].

\section{$7 \quad$ Information Systems Education for Development}

In the past two decades, discussions on the role of Information Systems as a discipline have taken place, as had to some extent, those on the role of ICT in general. Such discussions have evolved beyond the pre-occupation with attaining competitive advantage through improving productivity and efficiency within organizations [1]. One of the new discourses is the one concerned with how Information Systems are implicated in the process of national (as well as regional) development, specifically in the context of developing countries. In this stream many studies can be seen on IS and its implication to various socio-economic and political discourses such as public health, access to education, access to information, promotion of human rights as well as democracy and freedom just to name a few [2,3,4].

However, while the move towards the social implications has generated many useful insights on a form of theories and even practical knowledge, some areas of research have been largely ignored. One such area is the role of education, especially undergraduate education, in confronting the many challenges that have been repeatedly being raised by other ICT4D research [5]. This is particularly alarming considering what is already known as the impact of education in facilitating sustaining systemic changes into the society [6]. 
There have occasionally been generic mentions of the issue of shortage of skills or resources but this has often meant, at least to this author's interpretation, vocational or technical skills to implement the plans and ideas that are raised. There has also been substantial discussion on how many of the ICT4D challenges require a multidisciplinary approach, as opposed to being driven by just Computer Science, IT or IS. In some ways, this has often meant a collaboration at the research level (problem diagnosis level) and, in some cases, at the implementation level to mean creating diverse ICT4D project teams [17]. What has been lacking is theorizing on how this can be sustainably addressed at university level - specifically what it means for undergraduate studies. Heeks points out the need for ICT4D champions/leaders/professionals with understanding from three disciplines: Computer Science, Information Systems, and Developmental Studies [17]. However, he envisions this as something that can be done through master's programs. One review of ICT4D research in top IS journals and conferences, mentions education as the third most researched ICT4D theme after 'business' and 'empowerment' [38]. They do not, however, go into detail as to what aspects of education are the subjects of the research.

\section{Conclusion}

The above exploration of the link between IS, development, and education has clearly confirmed that IS as an academic discipline and a practical field in developing countries is still heavily influenced by positivist and instrumentalist perspectives. This is mostly attributed to the history of development as it has now come to be known, its long-term relationship with technology, as well as the history of the IS as a discipline. While there is an increasing focus on interpretive studies, as well as socially embedded initiatives that aim at developing local understandings and local IS solutions such initiatives are struggling to meaningfully transform the role of IS in the context of postcolonial developing countries. With few exceptions, IS is still seen as a means for organizations to improve productivity and efficiency for the purpose of increasing revenue. Practices such as software development, business process management, and project management are still initiated with the main intention of serving the often exploitative interest of corporations by maximizing profit with little concern for human impacts. In ICT4D, which is still confronted by high failure rates, there is very little evidence of IS paying a transformative role. On the contrary, most initiatives have been criticized for further entrenching the western superiority complex as well as developing solutions that feed-off the already asymmetric power relations between developed and the underdeveloped countries.

One way of dressing this challenge is through IS education, especially given the role education itself has played in establishing those practices in the first place. However, before IS education can be used as a means towards transformative and sustainable ICT4Ds, it needs to first undergo self-reflection and self-transformation. Fortunately, research points to a number of tools that can be used to diagnose and transform IS education. One such tool is critical research. A successful application of critical research in IS education can result in the transformation of IS education practices 
which over time can lead to the transformation of IS practices to ones that will challenge the existing social order and replace it with a new one that safeguards the interest of individuals and societies in developing countries.

\section{References}

1. Hirschheim, R., Klein, H.: A glorious and not-so-short history of the information systems field. Journal of the Association for Information Systems, 13(4), 188-235 (2012). Retrieved from http://aisel.aisnet.org/jais/vol13/iss4/5/.

2. Heeks, R.: Information systems and developing countries: Failure, success, and local improvisations. The Information Society, 18(2), 101-112 (2002).

3. Thompson, M., Walsham, G.: ICT research in Africa: Need for a strategic developmental focus. Information Technology for Development, 16(2), 112-127 (2010).

4. Walsham, G., Sahay, S.: Research on Information Systems in developing countries: Current landscape and future prospects. Information Technology for Development, 12(1), 724 (2006).

5. Bass, J. M., Heeks, R.: Changing computing curricula in African universities: Evaluating progress and challenges via design-reality gap analysis. The Electronic Journal on Information Systems in Developing Countries, 48(5), 1-39 (2011).

6. Freire, P. Pedagogy of the oppressed. Herder \& Herder, New York (1970).

7. Avgerou, C.: Information Systems in developing countries: A critical research review. Journal of Information Technology, 23(3), 133-146 (2008).

8. Roberts, T.: Critical intent \& practice in ICT4D: A typology of ICT4D initiatives. In: Proceedings of the 13th International Conference on Social Implications of Computers in Developing Countries, pp. 622-633, University of Oslo, Norway (2015).

9. Kleine, D. ICT4WHAT?-Using the choice framework to operationalise the capability approach to development. Journal of International Development, 22(5), 108-117 (2010).

10. Kleine, D., Unwin, T.: Technological revolution, evolution and new dependencies: What's new about ICT4D? Third World Quarterly, 30(5), 1045-1067 (2009).

11. Sahay, S.: Are we building a better world with ICTs? Empirically examining this question in the domain of public health in India. Information Technology for Development, 22(1), 168-176(2016).

12. Avgerou, C.: The link between ICT and economic growth in the discourse of development. In: Korpela, M., Montealegre, R., Poulymenakou, A. (eds.) Organizational Information Systems in the context of globalization, pp. 373-386. Springer Science + Business Media, New York (2003).

13. Poveda, S., Roberts, T.: Critical agency and development: applying Freire and Sen to ICT4D in Zambia and Brazil. Information Technology for Development, 0(0), 1-19 (2018).

14. Qureshi, S.: Are we making a better world with information and communication technology for development (ICT4D) research? Findings from the field and theory building. Information Technology for Development, 21(4), 511-522 (2015).

15. Walsham, G. ICT4D research: Reflections on history and future agenda. Information Technology for Development 23(1), 18-41 (2017).

16. Gopal, A., Wilis, R., Gopal, Y.; From Colonial Enterprise to Enterprise systems: Parallels between colonisations and globalization. In Prasad, A. (ed.): Postcolonial theory and organizational analysis: A critical engagement Palgrave Macmillan US (2003).

17. Heeks, R.: ICT4D 2.0: The next phase of applying ICT for international development. Computer, 41(6), 26-31 (2008). 
18. Murphy, J. T., Carmody, P., Surborg, B.: Industrial transformation or business as usual? Information and communication technologies and Africa's place in the global information economy. Review of African Political Economy, 41(140), 264-283 (2014).

19. Sen, A.: Development as Freedom. Oxford University Press (1999).

20. Cecez-Kecmanovic, D.: Basic assumptions of the critical research perspectives in Information Systems. In; Howcroft, D, Trauth, E. M. (eds.): Handbook of critical Information Systems research: Theory and application. : Edward Edgar, Cheltenham, UK; Northampton, MA (2005).

21. Orlikowski, W. J., Baroudi, J. J.:) Studying information technology in organizations: Research approaches and assumptions. Information Systems Research, 2(1), 1-28 (1991)

22. Rodney, W.: How Europe underdeveloped Africa.: East African Educational Publishers: Nairobi: (1972).

23. Ashcroft, B., Griffiths, G., Tiffin, H.: The post-colonial studies reader. Routledge, London \& New York (1995).

24. Prasad, A.): The gaze of the other: Postcolonial theory and Organisational analysis. In: Prasad, A. (ed.) Postcolonial theory and organizational analysis: A critical Engagement. Palgrave Macmillan, New York (2003)

25. Mazrui, A.: The African university as a multinational corporation: problems of penetration and dependency. Harvard Educational Review, 191-210 (1975).

26. Krauss, K.: Discourse and discourse collisions : Understanding the experiences of Information Systems students at a South African University. Proceedings of the 13th International Conference on Social Implications of Computers in Developing Countries, 665-682 (2015).

27. Miller, J. P., Seller, W.: Curriculum perspectives and practice. Addison-Wesley Longman, London (1985).

28. Dikson, G.): Management Information Systems: Evolution and status. In: M. Yovits (ed.) Advances in Computers (volume 20) pp. 1-39. Academic Press, New York: (1981)

29. Ashenhurst, R. L.: Curriculum recommendations for graduate professional programs in Information Systems. Communications of the ACM, 15(5), 363-398 (1972).

30. Couger, J.: Curriculum recommendations for undergraduate programs in Information Systems. Communications of the ACM, 16(12), 727-749 (1973)

31. Davis, G. B., Gorgone, J. T., Couger, J. D., Feinstein, D. L., Longenecker, H. E.: IS '97, model curriculum and guidelines for undergraduate degree programs in Information Systems. Database, 26(1), 1-94. (1997).

32. Topi, H., Valacich, J., Wright, R., Kaiser, K., Nunamaker, J., Sipior, J., De Vreede, G.: IS 2010: Curriculum guidelines for undergraduate degree programs in Information Systems. Communications of the Association for Information Systems, 26(1), 359-428 (2010).

33. Avgerou, C.: Information Systems: What sort of science is it? Information Society28(5), 567-579 (2007).

34. Ayalew, Y., Renken, J., Mgaya, K. V., Nkgau, T. Z.: Developing a contextualized Information Systems curriculum for an emerging economy. Electronic Journal of Information Systems in Developing Countries, 54(1), 1-19 (2012).

35. Krauss, K.: Collisions between the worldviews of international ICT policy-makers and a deep rural community in South Africa: Assumptions, interpretation, implementation, and reality. Information Technology for Development, 19(4), 296-318 (2013).

36. Vesisenaho, M.: ICT education and Computer Science education for development - Impact and Contextualization. In: 40th ASEE/IEEE Frontiers in Education Conference, pp. 1-6. Washington, DC (2010). 
37. Tedre, M., Bangu, N., Nyagava, S. I.: Contextualized IT education in Tanzania: Beyond standard IT curricula. Journal of Information Technology Education, 8. (1999).

38. Gomez, R., Baron, L. F., Fiore-Silfvast, B.: The changing field of ICTD: Content analysis of research published in selected journals and conferences, 2000-2010. ACM International Conference Proceeding Series, pp. 65-74(2012). 